\title{
EXOGENOUS APPLICATION OF 24-EPIBRASSINOLIDE AND NANO-ZINC OXIDE AT FLOWERING IMPROVES OSMOTIC STRESS TOLERANCE IN HARVESTED TOMATO SEEDS
}

\author{
JAVADI, A. ${ }^{1}-$ KHOMARI, S. ${ }^{1 *}-$ ESMAEILPOUR, B. ${ }^{2}-$ ASGHARI, A. ${ }^{1}$ \\ ${ }^{I}$ Department of Agronomy and Plant Breeding, Faculty of Agriculture and Natural Resources, \\ University of Mohaghegh Ardabili, Ardabil, Iran \\ (e-mail: Ahmadjavadi55@gmail.com; ali_asgharii@yahoo.com) \\ ${ }^{2}$ Department of Horticultural Sciences, Faculty of Agriculture and Natural Resources, \\ University of Mohaghegh Ardabili, Ardabil, Iran \\ (e-mail: bsmaielpoor2008@gmail.com) \\ *Corresponding author \\ e-mail: saeid.khomari@gmail.com \\ (Received $12^{\text {th }}$ Feb 2018; accepted $12^{\text {th }}$ Jun 2018)
}

\begin{abstract}
The favorable effects of exogenously applied brassinosteroids and zinc micronutrient on plant growth performance and seed development have been extensively outlined in many studies. Nevertheless, almost no published document is available on the effects of 24-epibrassinolide and nano-zinc oxide on tomato seed quality and osmotic stress tolerance of the resulted seedlings. In this study, the effects of 24epibrassinolide (0,15 and $\left.30 \mathrm{mg}^{-h^{-1}} \mathrm{EBL}\right)$ and nano-zinc oxide $(0,600$ and $1200 \mathrm{ppm} \mathrm{N-ZnO})$, which were exogenously applied on tomato mother plants, on seed germination parameters and stress tolerance capability of the produced seedlings under osmotic stress conditions (water potential of $0,-0.1$ and -0.2 MPa stimulated by PEG-6000) were investigated. According to obtained results, the water potential of $0.2 \mathrm{MPa}$ resulted in the lowest seed germinability and seedling growth performance with the highest amount of proline, hydrogen peroxide, malondialdehyde and activity of catalase and peroxidase, compared to non-stress control. All the foliar treatments resulted in decreased $\mathrm{H}_{2} \mathrm{O}_{2}$ and MDA content, especially $\mathrm{EBL}_{2}+\mathrm{N}-\mathrm{ZnO}_{2}$. In addition, foliar application of EBL and $\mathrm{N}-\mathrm{ZnO}$ enhanced the activity of antioxidative enzymes and ameliorated the inhibitory effects of osmotic stress on tomato seedling growth, except for percentage and rate of germination.
\end{abstract}

Keywords: antioxidant system, brassinosteroids, micronutrients, seed quality, water potential

\section{Introduction}

Tomato is the second most important vegetable crop next to potato worldwide (Eevera and Vanangamudi, 2006), and also it is highly popular in Northwest of Iran. According to the Food and Agriculture Organization (FAO), in 2016, around 4.7 million hectares of world farms allocated to tomatoes, which included about 177 million tons of annual production of fresh fruit (Anonymous, 2016). Tomato is mainly cultivated in tropical and sub-tropical countries, preferably in Mediterranean regions, which is mostly encountered by the varying environmental fluctuations. Among these adverse conditions, soil drying in seedbed is one of the critical problems that negatively influence seed germination and subsequent seedling growth (George, 2009; Chandrasekaran et al., 2017). The reduction in soil water potential results in disorder in seed germination by decreasing the imbibition rate (Eisvand et al., 2010). Individual seeds have to cross a threshold water potential in order to develop enzyme activity and lower their puncture force. The endosperm weakening opposite the radicle tip 
determines the threshold water potential for germination, which determines the rate and extent of germination (Finch-Savage, 2013).

In normal conditions, the reactive oxygen species (ROS) and antioxidant enzymes are produced in plant cells in a stable equilibrium (Gill and Tuteja, 2010), while under abiotic stresses, the balance can be overcome, mediating an accumulation of ROS and inducing oxidative damage (Mignolet-Spruyt et al., 2016). Lipid peroxidation as a main destructive event occurs due to increased ROS production and is detected by malondialdehyde accumulation in plant cells (Petrov et al., 2015). The antioxidant defense including the antioxidative enzymes (such as catalase and peroxidase) and metabolites is exploited by plant cells to cope with ROS attack (Gill and Tuteja, 2010). Catalase converts hydrogen peroxide $\left(\mathrm{H}_{2} \mathrm{O}_{2}\right)$ into water and molecular oxygen (DeLay, 2017). Peroxidase can also detoxify $\mathrm{H}_{2} \mathrm{O}_{2}$ using various compounds as electron donor (Puthur, 2016). In addition, some researchers have introduced proline as an antioxidant molecule, proposing its role as ROS scavenger along with compatible osmolyte (Hossain et al., 2014; Rejeb et al., 2014). Under osmotic stress condition, the high capacity of antioxidant system is essential for plants to scavenge ROS and then avoid oxidative stress (Uzilday et al., 2014).

To ensure optimum stand establishment in soils with low water content, high-quality seeds must be used to achieve rapid and uniform seedling emergence, which may improve the resources use efficiency of established seedlings (Copeland and McDonald, 2012; Taiz et al., 2015). High-quality, also known as high-vigor seed lot has a great potential for rapid and uniform seed germination and successful seedling emergence under stressful conditions (Ellis and Roberts, 1981; Rehman et al., 1999; de Figueiredo et al., 2003). In all horticultural plants, including tomato, the high-quality seeds are the most important input in an efficient plant production system. So that, the low-quality seeds result in the poor stand establishment and consequently lower the crop productivity, especially under abiotic stresses (Rashid and Singh, 2000; Elias et al., 2006; George, 2009).

Seed quality consists of the physiological, physical and health attributes and is influenced by the growth conditions of the mother plant, which is well known as 'maternal effect' (Sangkram and Noomhorm, 2002; Pfeifer et al., 2011). In tomato plant, the fruit as a surrounding environment directly transfers the external conditions to the developing seeds. In this respect, the phytohormones and the mineral nutrients that reach the seeds play a key role in plant cell metabolism and ultimately improve the quality of produced seeds (Srivastava and Handa, 2005). Overall, the internal concentrations of plant growth regulators such as brassinosteroids and nutritional status of the plant, especially after adequate supply of micronutrients during the formation and development of seeds on the mother plant, are so vital. Some researchers have previously reported the production of high-quality seeds in plants exogenously treated with brassinosteroids and zinc (Biesaga-Koscielniak et al., 2014; Laware and Raskar, 2014).

Brassinosteroids are the sixth group of phytohormones, which have different physiological effects on seed and seedling tissues including the stimulation of cell elongation and division, the regulation of enzymes activity and the promotion of seed germination (Özdemir et al., 2004). Previous researchers have reported that these compounds alleviate the detrimental impacts of environmental hazards such as drought, on plant performance (Prusakova et al., 2000; Vardhini et al., 2010). In this regard, Yuan et al. (2010) demonstrated that the exogenous application of 24-epibrassinolide 
mediated drought tolerance in tomato plants through reducing malondialdehyde and hydrogen peroxide and increasing the activity of antioxidant enzymes. The micronutrient element of Zinc ( $\mathrm{Zn}$ ) plays a fundamental role in plant metabolism (Marschner, 2011) and biosynthesis of RNA, DNA and proteins (Welch, 2001). Although zinc is required in small amounts (5-100 ppm), its complete lack or insufficiency may influence the important physiological aspects of plant growth (Baybordi, 2006) including antioxidative enzymes and some regulatory metabolites (Cakmak, 2000). Supplemental zinc can alleviate the negative impacts of oxidative damage on plant metabolism (Tavallali et al., 2010). For example, zinc can help maintain sulfhydryl groups of cell membrane, which are easily oxidized by ROS (Rengel, 1995; Rengel and Wheal, 1997).

Already, some efforts have been made to produce high-quality seeds by employing certain agronomic techniques. The aim of the present research was to evaluate the osmotic stress tolerance capability (as an indicator of seed quality) of tomato seeds harvested from mother plants subjected to 24-epibrassinolide and nano-zinc oxide at the flowering stage. In the present experiment, seed germinability and seedling growth indices were measured and the antioxidative enzyme activities, hydrogen peroxide, malondialdehyde and proline accumulation in tomato seedlings were determined. This work is important as it demonstrates the collaborative role of brassinosteroid and zinc micro-element in providing osmotic stress tolerance and creating awareness of the potential for tomato plants to be cultivated in arid and semi-arid areas.

\section{Materials and methods}

The present experiment was conducted during 2015-2016 growing season in the Department of Agronomyand Plant Breeding, Faculty of Agriculture and Natural Resoursec at the University of Mohaghegh Ardabili, Ardabil, Iran. The seed lot of tomato (Solanum lycopersicum L.) cv. Y was obtained from SPCRI (Seed and Plant Certification and Registration Institute, Karaj). The viability and moisture content of prepared seeds were about $98 \%$ and $8 \%$, respectively. All chemicals used in this research were purchased from Merck and Sigma-Aldrich.

Tomato seeds were sown in nursery beds of $0.5 \mathrm{~m} \times 0.5 \mathrm{~m}$, rich in loam and provided with shade and regular watering for seed germination. After 25 days of growth in the nursery, tomato plantlets were carefully transferred to the main field. The farm soil characteristics are listed in Table 1. The fertilizer application was $180 \mathrm{~kg} \mathrm{~N}, 150 \mathrm{~kg}$ $\mathrm{P}_{2} \mathrm{O}_{5}$ and $150 \mathrm{~kg} \mathrm{~K}$ per hectare. Tomato seedlings were transplanted in 3 rows in each plot at spacing of $45 \mathrm{~cm} \times 120 \mathrm{~cm}$, giving a total of 1500 plants per experimental unit. The final crop density was around 18,500 plants per hectare. A factorial experiment was conducted based on randomized complete block design (RCBD) with three replications. Experimental factors were foliar treatment combinations [control (only water), $15 \mathrm{mg} \cdot \mathrm{ha}^{-1}$ of 24-epibrassinolide $\left(\mathrm{EBL}_{1}\right), 30 \mathrm{mg} \cdot \mathrm{ha}^{-1}$ of 24-epibrassinolide $\left(\mathrm{EBL}_{2}\right)$, 600 ppm of nano-zinc oxide $\left(\mathrm{N}-\mathrm{ZnO}_{1}\right), 1200 \mathrm{ppm}$ of nano-zinc oxide $\left(\mathrm{N}-\mathrm{ZnO}_{2}\right), \mathrm{EBL}_{1}+$ $\left.\mathrm{N}-\mathrm{ZnO}_{1}, \mathrm{EBL}_{1}+\mathrm{N}-\mathrm{ZnO}_{2}, \mathrm{EBL}_{2}+\mathrm{N}-\mathrm{ZnO}_{1}, \mathrm{EBL}_{2}+\mathrm{N}-\mathrm{ZnO}_{2}\right]$ and osmotic stress levels $(0,-0.1$ and $-0.2 \mathrm{MPa})$. After complete vegetative growth in the field, foliar treatments with 24-epibrassinolide (EBL) and nano-zinc oxide $(\mathrm{N}-\mathrm{ZnO})$ were imposed at the flowering stage. Tween-20 $(0.1 \%)$ was used as surfactant to enhance the effectiveness of foliar spray. The foliar applications were made with a portable field sprayer at $150 \mathrm{kPa}$ pressure with $1000 \mathrm{l}$ of liquid applied per hectare. 
Table 1. Soil characteristics of the farm where the experiment was conducted

\begin{tabular}{c|c}
\hline Characteristics & Values \\
\hline Soil texture & Loam \\
$\mathrm{pH}\left(1: 1 \mathrm{H}_{2} \mathrm{O}\right)$ & 7.4 \\
$\mathrm{EC}_{\mathrm{e}}\left(\mathrm{dS} \cdot \mathrm{m}^{-1}\right)$ & 3.8 \\
Organic carbon $(\%)$ & 0.9 \\
Total N $(\%)$ & 0.09 \\
Available $\mathrm{P}\left(\mathrm{mg}_{\mathrm{kg}} \mathrm{kg}^{-1}\right)$ & 20 \\
Available K $\left(\mathrm{mg}_{\mathrm{kg}}{ }^{-1}\right)$ & 230 \\
Zn $\left(\mathrm{mg} \cdot \mathrm{kg}^{-1}\right)$ & 0.994 \\
\hline
\end{tabular}

After harvesting the fully ripe fruits, the seeds were extracted by fermentation method (at $25{ }^{\circ} \mathrm{C}$ for $24 \mathrm{~h}$ ) and then dried to moisture content of about $8 \%$. The quality of obtained seeds was assayed under osmotic stress condition. In order to create the different water stress levels $(0,-0.1$ and $-0.2 \mathrm{MPa})$ in seed germination mediums, PEG6000 was used. The standard germination test of the processed seeds was conducted according to the rules approved by the International Seed Testing Association (ISTA, 2008). In brief, after 10 min of surface sterilization with sodium hypochlorite $1 \%$, four replicates of 50 seeds were incubated in alternating temperatures $\left(25 / 30{ }^{\circ} \mathrm{C}\right)$ for 14 days. The daily counting of the number of germinated seeds $(>2 \mathrm{~mm}$ radicle protrusion) continued until the end of the 14th day. In each experimental unit, the standard germination percentage and dry weight and length of seedlings were measured. The germination rate was calculated using the formula of Ellis and Roberts (1981). The vigor index (VI) was calculated using the following equation: $\mathrm{VI}=$ seedling length $\times$ germination percentage.

Free proline content in tomato seedlings was determined using ninhydrin reagent according to the most used method described by Bates et al. (1973). Malondialdehyde (MDA) content was measured by thiobarbituric acid reaction (Heath and Packer, 1968), with slight modifications. Fresh seedlings $(0.1 \mathrm{~g}$ each) were homogenized in $1 \mathrm{ml}$ of $0.1 \%(\mathrm{w} / \mathrm{v})$ trichloroacetic acid (TCA) and the homogenates were centrifuged at $5000 \times \mathrm{g}$ for $10 \mathrm{~min}$ at $4{ }^{\circ} \mathrm{C}$. In the following, $400 \mu \mathrm{l}$ of the supernatant was added into 1 $\mathrm{ml}$ of $0.5 \%(\mathrm{w} / \mathrm{v})$ thiobarbituric acid. The obtained mixture was incubated at a temperature of $95{ }^{\circ} \mathrm{C}$ in a water bath for $30 \mathrm{~min}$. After centrifugation at $10000 \times \mathrm{g}$ for $10 \mathrm{~min}$, the absorbance of the supernatant was measured at 532 and $600 \mathrm{~nm}$ in a spectrophotometer. To calculate the concentration of MDA, the related extinction coefficient $\left(0.155 \mu \mathrm{M}^{-1} . \mathrm{cm}^{-1}\right)$ was used and the values were expressed as $\mu$ mol.g ${ }^{-1} \mathrm{~F}$.W. Hydrogen peroxide was quantified by the method of Hung et al. (2005). Fresh seedlings $(0.1 \mathrm{~g}$ each) were homogenized in $1 \mathrm{ml}$ of $0.1 \%$ (w/v) TCA. The obtained mixture was centrifuged at $10000 \times \mathrm{g}$ for $10 \mathrm{~min}$, at $4{ }^{\circ} \mathrm{C}$, then $0.5 \mathrm{ml}$ of supernatant was added to $0.5 \mathrm{ml}$ of $10 \mathrm{mM}$ potassium phosphate buffer $(\mathrm{pH}=7)$ and $1 \mathrm{ml}$ of $1 \mathrm{mM}$ potassium iodide. The absorbance was read at a wavelength of $390 \mathrm{~nm}$. The amount of hydrogen peroxide in each sample was calculated using the specific extinction coefficient $(0.28$ $\mu \mathrm{M}^{-1} . \mathrm{cm}^{-1}$ ) and the values were expressed in units of $\mu$ mol.g ${ }^{-1}$ F.W. Catalase (CAT) and peroxidase (POD) activities in tomato seedlings were assayed using the methods of Aebi (1984) and MacAdam et al. (1992), respectively. 
After conducting the normality test of obtained data, two-way analysis of variance (ANOVA) for randomized complete block design was done using SAS 9.4 software and the means were compared by least significant difference (LSD) test at $5 \%$ probability level and the figures were created with Microsoft Excel 2013.

\section{Results}

In the present study, tomato plants were exogenously treated with different combinations of 24-epibrassinolide (EBL) and nano-zinc oxide $(\mathrm{N}-\mathrm{ZnO})$ at the flowering stage and then the harvested seed lots were subjected to osmotic stress (OS). Finally, germination percentage and rate, seedling length, dry weight and vigor index, proline, malondialdehyde and $\mathrm{H}_{2} \mathrm{O}_{2}$ content and catalase and peroxidase activity in the seedlings were estimated. In general, the main effects and interaction of two experimental factors: (1) foliar application of EBL+N-ZnO and (2) osmotic stress were statistically significant $(P \leq 5 \%)$ in all measured characteristics, but germination percentage and rate which had the main effects, were significant (Table 2).

Table 2. Analysis of variance of EBL+N-ZnO effects on some characteristics related to seed germination and seedling growth performance of tomato under drought stress condition

\begin{tabular}{|c|c|c|c|c|c|c|}
\hline \multirow[b]{2}{*}{ S.O.V. } & \multirow[b]{2}{*}{ d.f. } & \multicolumn{5}{|c|}{ Mean squares } \\
\hline & & $\begin{array}{c}\text { Germination } \\
\text { percentage }\end{array}$ & $\begin{array}{c}\text { Germination } \\
\text { rate }\end{array}$ & $\begin{array}{c}\text { Seedling } \\
\text { length }\end{array}$ & $\begin{array}{c}\text { Seedling } \\
\text { weight }\end{array}$ & $\begin{array}{l}\text { Vigour } \\
\text { index }\end{array}$ \\
\hline Block & 2 & $1.148^{\mathrm{ns}}$ & $0.0066^{* * *}$ & $0.031^{* * *}$ & $0.0002^{\mathrm{ns}}$ & $0.13^{\mathrm{ns}}$ \\
\hline $\mathrm{EBL}+\mathrm{N}-\mathrm{ZnO}$ & 8 & $170.527^{* *}$ & $0.0094^{* *}$ & $4.714^{* *}$ & $0.0538^{* *}$ & $11.126^{* *}$ \\
\hline Drought stress & 2 & $148.111^{* *}$ & $0.453^{* *}$ & $96.123^{* * *}$ & $1.09^{* *}$ & $176.553^{* *}$ \\
\hline $\mathrm{EBL}+\mathrm{N}-\mathrm{ZnO} \times$ drought stress & 16 & $1.486^{\mathrm{ns}}$ & $0.00001^{\mathrm{ns}}$ & $1.008^{* *}$ & $0.0113^{* *}$ & $0.973^{* *}$ \\
\hline Error & 52 & 5.827 & 0.0005 & 0.0038 & 0.00006 & 0.135 \\
\hline C.V. (\%) & - & 2.360 & 5.522 & 1.403 & 1.486 & 2.625 \\
\hline \multicolumn{7}{|c|}{ Continuation } \\
\hline \multirow[b]{2}{*}{ S.O.V. } & \multirow[b]{2}{*}{ d.f. } & \multicolumn{5}{|c|}{ Mean squares } \\
\hline & & $\begin{array}{l}\text { Proline } \\
\text { content }\end{array}$ & $\begin{array}{c}\text { Hydrogen } \\
\text { peroxide } \\
\text { content }\end{array}$ & $\begin{array}{l}\text { Malondialdehyde } \\
\text { content }\end{array}$ & $\begin{array}{l}\text { Catalase } \\
\text { activity }\end{array}$ & $\begin{array}{l}\text { Peroxidase } \\
\text { activity }\end{array}$ \\
\hline Block & 2 & $4733.405^{\mathrm{ns}}$ & $0.0009^{\mathrm{ns}}$ & $0.0008^{* *}$ & $0.000002^{*}$ & $0.00001^{\mathrm{ns}}$ \\
\hline $\mathrm{EBL}+\mathrm{N}-\mathrm{ZnO}$ & 8 & $152822.922^{* *}$ & $0.157^{* *}$ & $0.287^{* *}$ & $0.00008^{* *}$ & $0.0003^{* *}$ \\
\hline Drought stress & 2 & $2794500.611^{* *}$ & $3.344^{* *}$ & $1.216^{* *}$ & $0.0012^{* *}$ & $0.0150^{* *}$ \\
\hline $\mathrm{EBL}+\mathrm{N}-\mathrm{ZnO} \times$ drought stress & 16 & $27339.950^{* *}$ & $0.033^{* *}$ & $0.075^{* *}$ & $0.0002^{* *}$ & $0.0001^{* *}$ \\
\hline Error & 52 & 5188.522 & 0.0004 & 0.050 & 0.000001 & 0.0002 \\
\hline C.V. (\%) & - & 1.713 & 3.032 & 7.609 & 1.575 & 2.870 \\
\hline
\end{tabular}

The effect of osmotic stress on the germination percentage and rate of seeds produced from tomato mother plants exogenously treated with EBL and N-ZnO are shown in Table 3. Overall, the promotive influence of foliar application of EBL and N$\mathrm{ZnO}$ on the germination percentage and rate were observed. The treatment, $\mathrm{EBL}_{1}$ $\left(15 \mathrm{mg} \cdot \mathrm{ha}^{-1}\right)$, had no significant difference from control $(P>5 \%)$ in percentage germination. The sole applications of EBL and $\mathrm{N}-\mathrm{ZnO}$ were statistically the same in the rate of germination. The highest germination percentage and rate were recorded when $\mathrm{EBL}_{2}+\mathrm{N}-\mathrm{ZnO}_{2}$ was applied in the mother plants, compared to control in which only the 
distilled water was sprayed. The germination percentage and rate was significantly decreased with increased levels of osmotic stress. So that, the maximum reduction in germination percentage (about 5\%) and rate (approximately 72\%) were observed in water potential of $-0.2 \mathrm{MPa}$ compared with control.

Table 3. Germination percentage and rate of seeds harvested from tomato plants subjected to exogenous EBL and $\mathrm{N}-\mathrm{ZnO}$ in response to osmotic stress

\begin{tabular}{|c|c|c|c|}
\hline \multicolumn{2}{|c|}{ Experimental factors } & Germination percentage & Germination rate $\left(d^{-1}\right)$ \\
\hline \multirow{9}{*}{$\begin{array}{l}\text { Foliar application of } \\
\text { EBL and } \mathrm{N}-\mathrm{ZnO}\end{array}$} & Control & $84.0 \pm 1.756 \mathrm{f}$ & $0.164 \pm 0.039 \mathrm{e}$ \\
\hline & $\mathrm{EBL}_{1}\left(15 \mathrm{mg} \cdot \mathrm{ha}^{-1}\right)$ & $85.8 \pm 1.839 \mathrm{fe}$ & $0.178 \pm 0.038 \mathrm{~d}$ \\
\hline & $\mathrm{EBL}_{2}\left(30 \mathrm{mg} \cdot \mathrm{ha}^{-1}\right)$ & $92.4 \pm 1.732 \mathrm{c}$ & $0.185 \pm 0.037 \mathrm{~d}$ \\
\hline & $\mathrm{N}-\mathrm{ZnO}_{1}(600 \mathrm{ppm})$ & $87.3 \pm 1.849 \mathrm{e}$ & $0.182 \pm 0.037 \mathrm{~d}$ \\
\hline & $\mathrm{N}-\mathrm{ZnO}_{2}(1200 \mathrm{ppm})$ & $90.0 \pm 1.636 \mathrm{~d}$ & $0.181 \pm 0.041 \mathrm{~d}$ \\
\hline & $\mathrm{EBL}_{1}+\mathrm{N}-\mathrm{ZnO}_{1}$ & $89.8 \pm 1.632 \mathrm{~d}$ & $0.197 \pm 0.038 \mathrm{dc}$ \\
\hline & $\mathrm{EBL}_{1}+\mathrm{N}-\mathrm{ZnO}_{2}$ & $93.7 \pm 1.563 b c$ & $0.221 \pm 0.037 \mathrm{c}$ \\
\hline & $\mathrm{EBL}_{2}+\mathrm{N}-\mathrm{ZnO}_{1}$ & $92.1 \pm 1.501 \mathrm{~b}$ & $0.244 \pm 0.041 \mathrm{ab}$ \\
\hline & $\mathrm{EBL}_{2}+\mathrm{N}-\mathrm{ZnO}_{2}$ & $97.1 \pm 1.444 \mathrm{a}$ & $0.263 \pm 0.038 \mathrm{a}$ \\
\hline LSD (5\%) & & 2.283 & 0.0346 \\
\hline \multirow{3}{*}{ Osmotic stress } & Control & $93.1 \pm 0.590 \mathrm{a}$ & $0.347 \pm 0.009 \mathrm{a}$ \\
\hline & $-0.1 \mathrm{MPa}$ & $89.9 \pm 0.773 b$ & $0.165 \pm 0.008 b$ \\
\hline & $-0.2 \mathrm{MPa}$ & $88.1 \pm 0.735 \mathrm{c}$ & $0.097 \pm 0.008 \mathrm{c}$ \\
\hline LSD (5\%) & & 1.318 & 0.02 \\
\hline
\end{tabular}

Similar letters indicate no significant difference at $\mathrm{p} \leq 5 \%$

Changes in the length, dry weight and vigor index of tomato seedlings in response to treatment compounds almost followed the same trend (Fig. 1 A-C). Overall, the foliar treatments of EBL and $\mathrm{N}-\mathrm{ZnO}$ significantly increased the seedling growth parameters, compared to untreated control (only water spray). On the other hand, the inhibitory effect of osmotic stress on the growth performance of tomato seedlings was intensified by decreasing the water potential. The highest values of seedling length (Fig. 1A), dry weight (Fig. 1B) and vigor index (Fig. $1 C$ ) were recorded in treatment combination of $\mathrm{EBL}_{2}+\mathrm{N}-\mathrm{ZnO}_{2}$ under nonstress condition. The lowest length, dry weight and vigor index of tomato seedlings belonged to both $\mathrm{N}-\mathrm{ZnO}_{1}$ (600 ppm of nano-zinc oxide) and untreated control, when $-0.2 \mathrm{MPa}$ water potential was created in the growth medium. Notably, when the osmotic stress was amplified in seedling growth medium (-0.2 MPa water potential), the effectiveness of exogenously applied brassinosteroid and zinc was relatively maintained in comparison with the mild water deficit condition (-0.1 MPa water potential).

The free proline content in tomato seedlings was significantly influenced by osmotic stress levels $(P \leq 0.05)$. In an osmotic potential of $-0.2 \mathrm{MPa}$, the accumulation of proline was increased approximately by $15 \%$ compared to non-stress control. In general, the foliar treatments had negligible but significant positive effects on the proline amount $(P>0.05)$. On the other hand, the interaction between the two experimental factors was statistically significant. The proline content was considerably elevated in response to concomitant application of 24-epibrassinolide and nano-zinc oxide under both osmotic stress levels, so that the highest proline accumulation occurred in treatment combination of $\mathrm{EBL}_{2}+\mathrm{N}-\mathrm{ZnO}_{2}$ under water potential of $-0.2 \mathrm{MPa}$ (Fig. 2). 

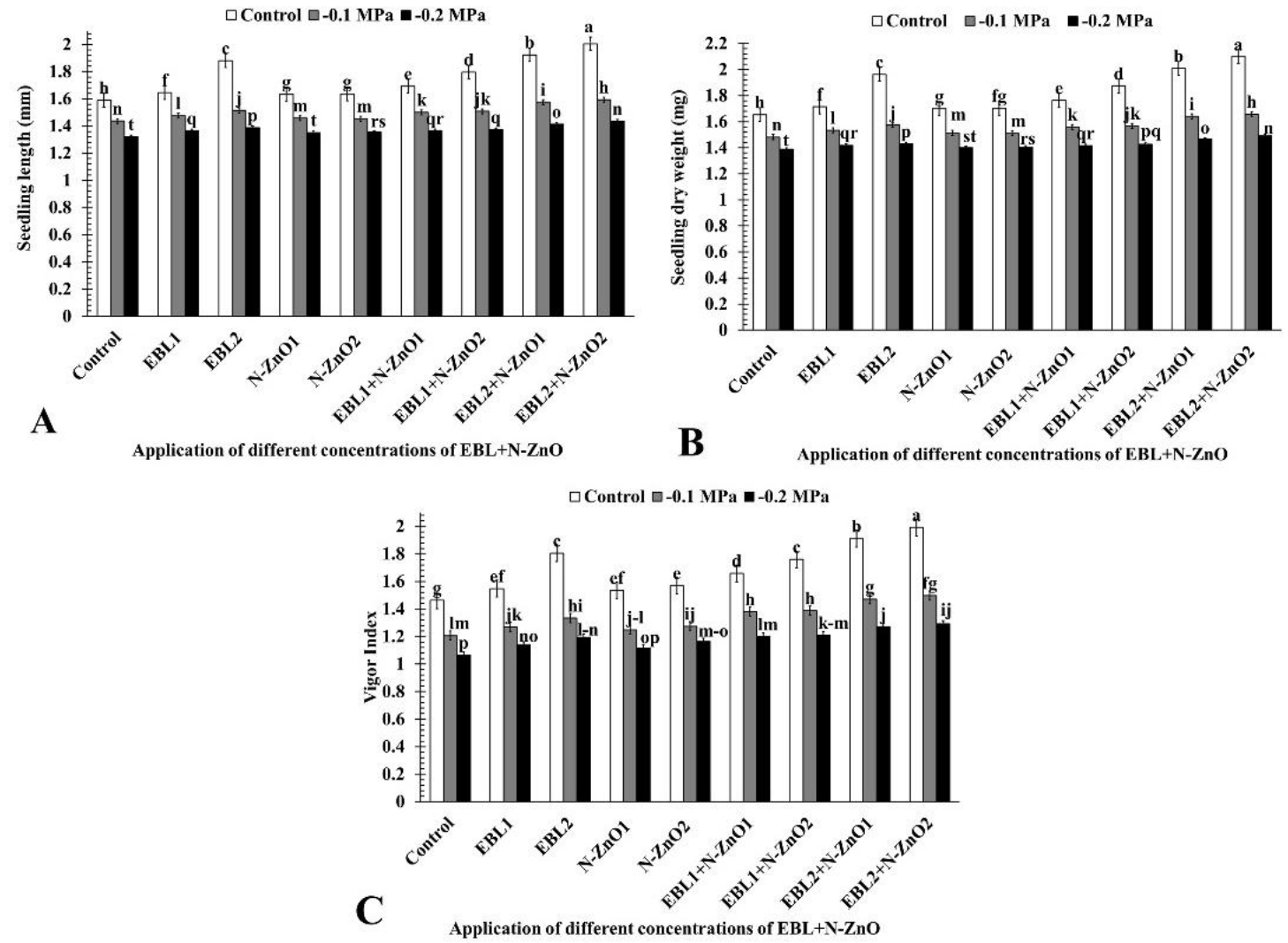

Figure 1. Changes in the seedling length $(A)$, dry weight $(B)$ and vigor index $(C)$ in response to foliar spray treatments (EBL and $\mathrm{N}-\mathrm{ZnO}$ ) applied on tomato mother plants and osmotic stress applied in the germination medium of produced seeds. Similar letters indicate no significant difference at $P \leq 5 \%$. LSD values for the seedling length, dry weight and vigor index were 0.01, 0.0134 and 0.06 , respectively

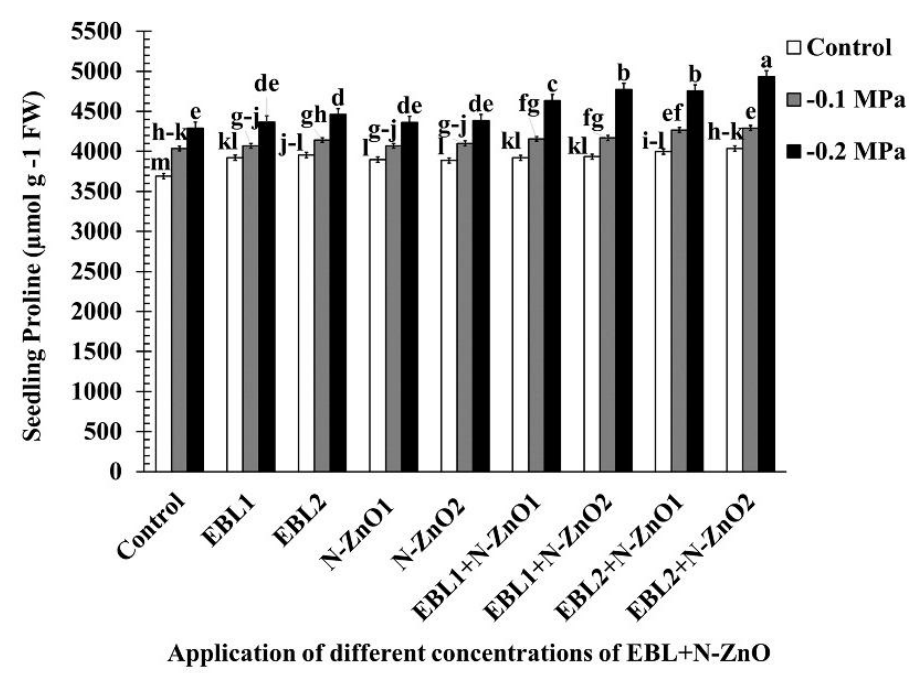

Figure 2. Changes in the free proline content of seedling in response to foliar spray treatments (EBL and $\mathrm{N}-\mathrm{ZnO}$ ) applied on tomato mother plants and osmotic stress applied in the germination medium of produced seeds. Similar letters indicate no significant difference at $P \leq 5 \%$. LSD value was 118.02 
The tomato seedlings showed the higher $\mathrm{H}_{2} \mathrm{O}_{2}$ accumulation under osmotic stress compared to the corresponding control, especially when the osmotic potential of the culture medium was $-0.2 \mathrm{MPa}$ (Fig. 3). Under both non-stress and osmotic stress conditions, foliar sprayed $\mathrm{EBL}+\mathrm{N}-\mathrm{ZnO}$ combination had more significant reduction in the $\mathrm{H}_{2} \mathrm{O}_{2}$ accumulation compared to sole application of EBL and/or N-ZnO. The lowest $\mathrm{H}_{2} \mathrm{O}_{2}$ content was clearly observed in $\mathrm{EBL}_{2}+\mathrm{N}-\mathrm{ZnO}_{2}\left(30 \mathrm{mg} \cdot \mathrm{ha}^{-1} \mathrm{EBL}\right.$ and $1200 \mathrm{ppm}$ $\mathrm{N}-\mathrm{ZnO}$ ) under non-stress condition. Among the sole applications of 24-epibrassinolide $\left(\mathrm{EBL}_{1}\right.$ and $\left.\mathrm{EBL}_{2}\right)$ and nano-zinc oxide $\left(\mathrm{N}-\mathrm{ZnO}_{1}\right.$ and $\left.\mathrm{N}-\mathrm{ZnO}_{2}\right), 30 \mathrm{mg} \cdot \mathrm{ha}^{-1}$ brassinosteroid $\left(\mathrm{EBL}_{2}\right)$ showed more decrease in hydrogen peroxide amount.

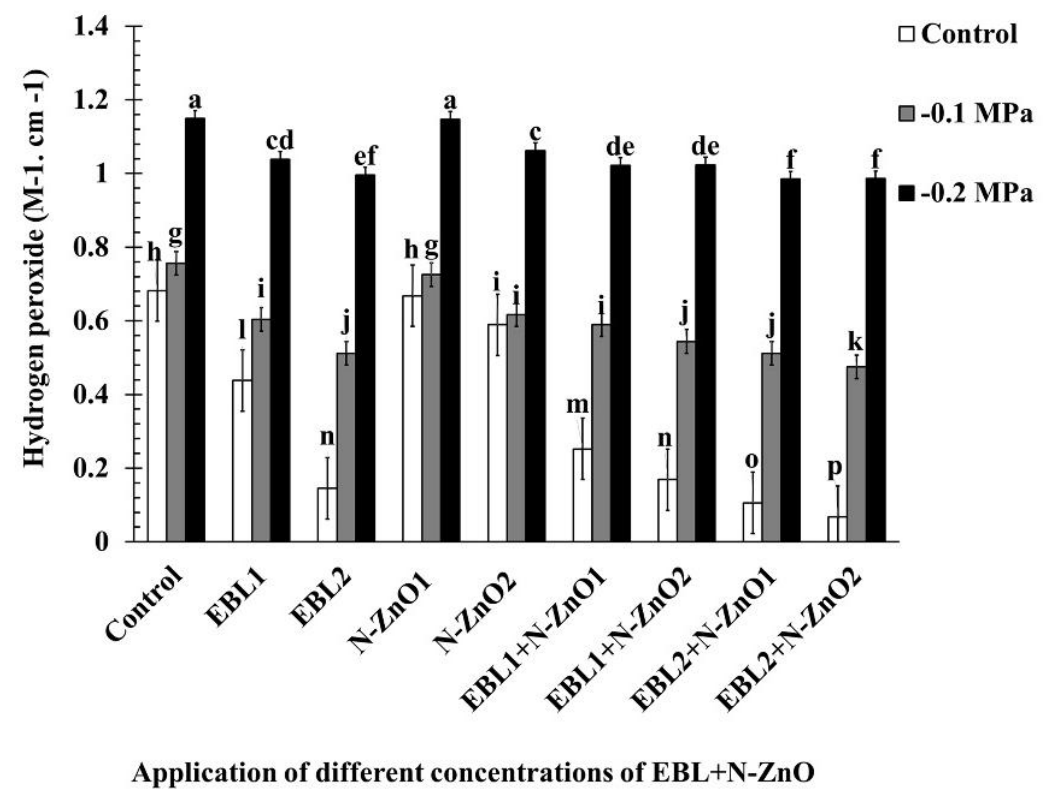

Figure 3. Changes in the $\mathrm{H}_{2} \mathrm{O}_{2}$ content of seedling in response to foliar spray treatments (EBL and $\mathrm{N}-\mathrm{ZnO}$ ) applied on tomato mother plants and osmotic stress applied in the germination medium of produced seeds. Similar letters indicate no significant difference at $P \leq 5 \%$. LSD value was 0.0328

The osmotic stress led to a significant increase in malondialdehyde (MDA) content in tomato seedlings compared to corresponding control (Fig. 4). The greatest accumulation of MDA was recorded in tomato seedlings untreated with EBL and N$\mathrm{ZnO}$ under osmotic stress level of $-0.2 \mathrm{MPa}$. Among the sole applications of brassinosteroid and zinc, $\mathrm{EBL}_{2}\left(30 \mathrm{mg} \cdot \mathrm{ha}^{-1}\right)$ indicated more reduction in MDA content. Overall, the osmotic stress-induced MDA production was further restricted when $\mathrm{EBL}+\mathrm{N}-\mathrm{ZnO}$ combinations were exogenously applied, instead of using them alone. The lowest accumulation of malondialdehyde was observed in $\mathrm{EBL}_{2}+\mathrm{N}-\mathrm{ZnO}_{2}$ treatment under all three levels of osmotic stress.

As shown in Figure 5, the catalase activity in tomato seedlings was significantly increased under osmotic stress condition (-0.1 and -0.2 MPa) compared to control, and the foliar treatments relatively enhanced the CAT activity. The highest activity of catalase (about 3-fold of control) was observed in water potential of $-0.2 \mathrm{MPa}$ when $30 \mathrm{mg} \cdot \mathrm{ha}^{-1} \mathrm{EBL}$ and $1200 \mathrm{ppm} \mathrm{N-ZnO}$ were concomitantly applied. 


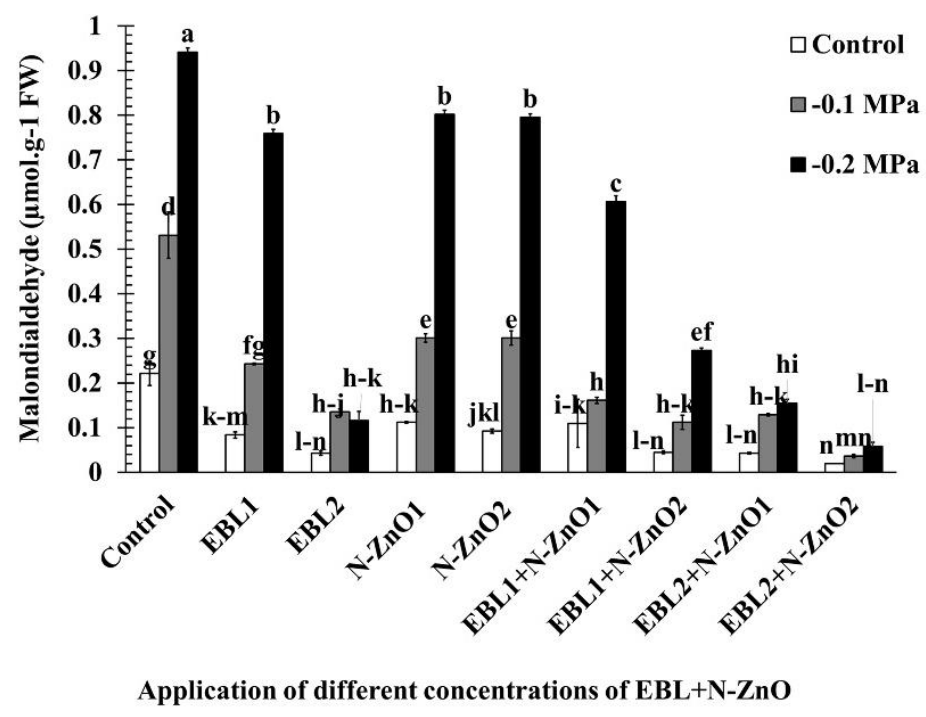

Figure 4. Changes in the MDA content of seedling in response to foliar spray treatments (EBL and $\mathrm{N}-\mathrm{ZnO}$ ) applied on tomato mother plants and osmotic stress applied in the germination medium of produced seeds. Similar letters indicate no significant difference at $P \leq 5 \%$. LSD value was 0.0509

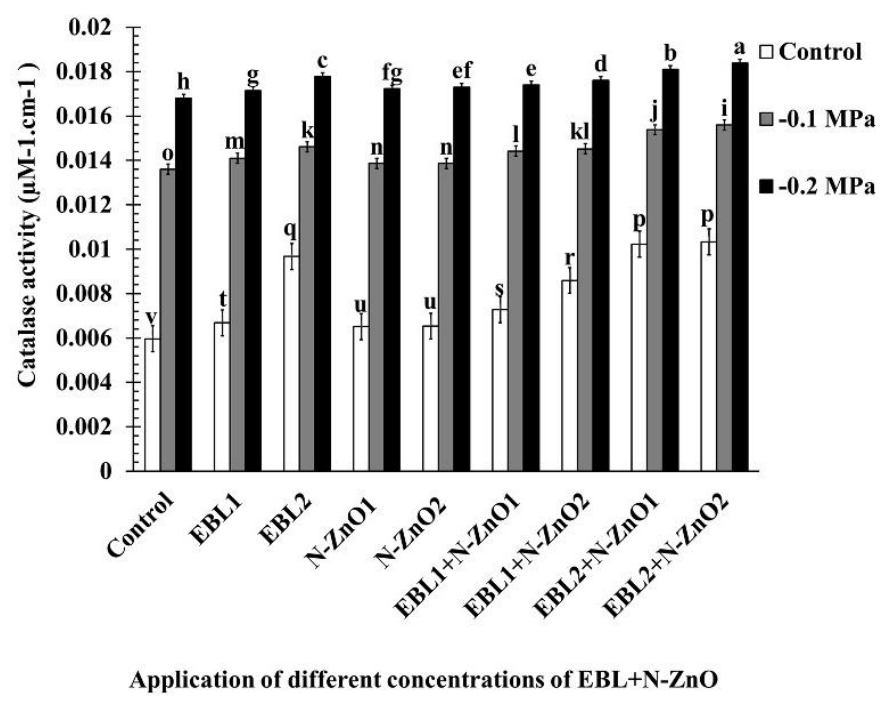

Figure 5. Changes in the activity of CAT in response to foliar spray treatments (EBL and $N$ $\mathrm{ZnO}$ ) applied on tomato mother plants and osmotic stress applied in the germination medium of produced seeds. Similar letters indicate no significant difference at $P \leq 5 \%$. LSD value was 0.0001

Under non-stress conditions, foliar sprayed EBL and $\mathrm{N}-\mathrm{ZnO}$ did not have any significant effect on the peroxidase activities (Fig. 6). Under osmotic stress, the activities of POD in tomato seedlings were obviously increased, whereas the application of 24-epibrassinolide and nano-zinc oxide negligibly but significantly promoted the increase. Like the CAT enzyme, the highest activity of POD (more than two fold of control) was recorded in treatment combination of $\mathrm{EBL}_{2}+\mathrm{N}-\mathrm{ZnO}_{2}$ under water potential of $-0.2 \mathrm{MPa}$. 


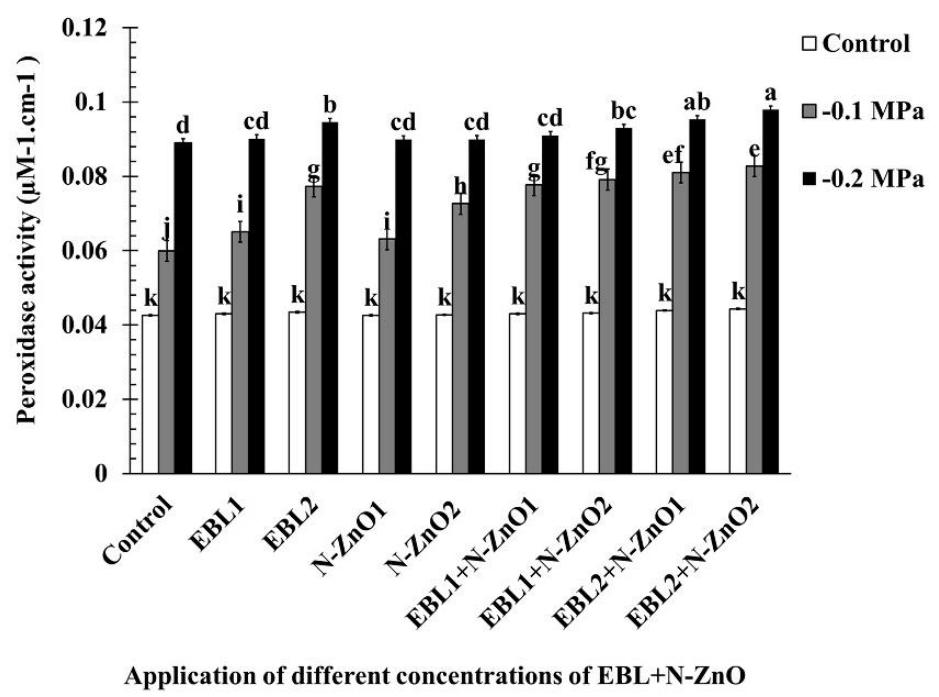

Figure 6. Changes in the activity of POD in response to foliar spray treatments ( $E B L$ and $N-\mathrm{ZnO}$ ) applied on tomato mother plants and osmotic stress applied in the germination medium of produced seeds. Similar letters indicate no significant difference at $P \leq 5 \%$. LSD value was 0.0033

\section{Discussion}

Promotive effects of brassinosteroid and zinc micronutrient on seed quantity and quality of field crops has already been mentioned by some authors (Hayat et al., 2001; Biesaga-Koscielniak et al., 2014; Laware and Raskar, 2014). According to previous studies, exogenous application of 24-epibrassinolide (Özdemir et al., 2004) and nanozinc oxide (Prasad et al., 2012) at germination stage can lead to improved seed germinability and subsequent seedling growth. To the best of our knowledge, almost no research has been conducted to evaluate the effects of foliar spray of EBL and $\mathrm{N}-\mathrm{ZnO}$ on seed germination and subsequent seedling performance under osmotic stress condition in seed lots produced from tomato mother plants. In the present research, the results showed that osmotic stress resulted in a delayed and decreased germination, which was not improve by foliar application of EBL and $\mathrm{N}-\mathrm{ZnO}$ in tomato plants (Table 2). The results are in good agreement with previous investigations which reported osmotic stress-induced reduction in the seed germinability (PENG et al., 2013; Bhatt et al., 2015). Rajabi et al. (2013) stated that interruption in water absorption by seed could affect the metabolic activities related to germination process under osmotic stress condition. On the other hand, foliar spray of EBL and $\mathrm{N}-\mathrm{ZnO}$ combinations at the flowering stage could enhance the percentage and rate of germination in the obtained seeds (Table 2). Brassinosteroids have a similar role as gibberellin in the germination process and enhances the germinability of seeds by reducing and/or increasing their biosynthesis and sensitivity to abscisic acid and/or gibberellin, respectively (Erik et al., 1996; Steber and McCourt, 2001; Zhang et al., 2009; Divi and Krishna, 2010). Similar results have reported that exogenous application of zinc in safflower (MovahhedyDehnavy et al., 2009) and soybean (Sedghi et al., 2013) increased the germination of produced seeds under drought stress conditions. Zinc micro-element is required for the biosynthesis of auxin (IAA) through the tryptamine pathway (Haslett et al., 2001), and has a promotive effect on the cell division (Alloway, 2004). Therefore, it can be 
concluded that $\mathrm{Zn}$-mediated increase in the seed germination parameters can be originated from the signaling of IAA and the proliferation of cells.

According to the present results, the tomato seedling performance (measured as seedling length, dry weight and vigor index) was adversly affected when osmotic stress was intensified in the culture medium of harvested seeds. As seen in Figure 1, 30 mg.ha ${ }^{-1}$ EBL along with 1200 ppm N-ZnO (treatment combination of $\mathrm{EBL}_{2}+\mathrm{N}$ $\mathrm{ZnO}_{2}$ ) may to a great extent compensate for the drought-induced inhibition in tomato seedling growth. The results of the current study are consistent with the recent study (Khripach et al., 1998) in which the growth performance of seedlings was improved when the mother plants was treated with 24-epibrassinolide and the harvested seeds were exposed to low water potentials. Prasad et al. (2012) demonstrated that the foliar spray of nano-zinc oxide caused a significant increase in seedling length and dry weight, compared to the control. Boonchuay et al. (2013) found that foliar application of zinc resulted in higher seedling vigor index in seed lots obtained from exogenously treated mother plants. Overall, nanoparticles provide an efficient means to distribute agro-chemicals including fertilizers, in a controlled fashion (Agrawal and Rathore, 2014). So, plants can rapidly absorb slow-release nano-fertilizers and surely cause the saving of fertilizer consumption and minimize environmental pollution (Mura et al., 2013; Bindraban et al., 2015). It should be noted that the hormone (24-epibrassinolide) application was more efficient than the micronutrient (nano-zinc oxide), when only one of them was used alone, compared to EBL $+\mathrm{N}-\mathrm{ZnO}$ co-application.

In consistency with the results of this experiment, many researchers reported that osmotic stress increases the accumulation of free proline in tomato seedlings (CalvoPolanco et al., 2016; Sun et al., 2016). Kishor et al. (2014) stated that the proline accumulation has a positive and direct relationship with increasing the tolerance to water deficit stress in plants, as was evident in the current study (Fig. 2). Further increase in proline amount leads to preventing ROS attack and subsequently reducing the cell membrane damage. In addition, drought tolerance is increased by prolineinduced osmotic adjustment (Szabados and Savouré, 2010). On the other hand, exogenous $\mathrm{EBL}$ and $\mathrm{N}-\mathrm{ZnO}$, exogenously applied in tomato mother plants during anthesis, promotes the production of free proline in seedlings under low water potential (Fig. 2). In this regard, Behnamnia et al. (2009) reported that 24-epibrassinolide increased the proline content in tomato leaves under limited water access. It has commonly been assumed that, EBL can promote free proline biosynthesis through inducing the expression of genes responsible for the related enzymes (Talaat and Shawky, 2013) and regulating the synthesis of nucleic acids (Bajgaz, 2000). As an important cofactor, Zinc has a key role in the production and activity of several enzymes (Bagci et al., 2007), particularly those involved in the main pathway of proline biosynthesis, i.e. glutamate pathway which is dominant in higher plants (Delaney et al., 1993). So, it seems that great increase in the proline content of tomato seedlings in response to exogenous application of EBL and $\mathrm{N}-\mathrm{ZnO}$ at the flowering stage can help maintain an efficient osmotic homeostasis into the cell (by increasing proline and other compatible osmolytes), and therefore induce the osmotic stress tolerance in seedlings.

In this study, the hydrogen peroxide (Fig. 3) and malondialdehyde (Fig. 4) accumulation was clearly observed in leaves in response to low water potential imposed to seedlings from harvested tomato seeds. There is strong evidence that osmotic stress can result in the accumulation of ROS including hydrogen peroxide and MDA, as an indicator of lipid peroxidation, in different plant tissues (Todorova et al., 2016). As previous studies 
have emphasized, the overproduction of toxic ROS in plant cells under stress can mainly damage the lipid-containing components of cell (Tavallali et al., 2010) and then cause the plasma membrane disintegrity that increases the permeabilization (Anjum, 2015). As found in the present experiment, osmotic stress-induced accumulation of $\mathrm{H}_{2} \mathrm{O}_{2}$ and MDA in seedlings was significantly declined as a result of foliar treatment of tomato mother plants with 24-epibrassinolide and nano-zinc oxide (Figs. 3 and 4). Several researchers reported the decline in $\mathrm{H}_{2} \mathrm{O}_{2}$ and MDA content of leaves due to 24-epibrassinolide application (Yuan et al., 2010; Talaat and Shawky, 2013). Brassinosteroid hormones may prevent the membrane damage caused by lipid peroxidation through influencing fatty acid composition and regulating the expression of genes (Khripach et al., 1998; Cao et al., 2005). In addition, $\mathrm{Zn}$ reduced ROS generation by indirect activation of antioxidant system (Grewal and Wiliams, 2000; Bagci et al., 2007).

Higher plants evolutionary have an antioxidant defense mechanism for scavenging reactive oxygen species, and efficient modulation of this defense system is essential for plants to tolerate the stress-iduced oxidative damage (Mittova et al., 2015). In the present study, antioxidative enzymes including catalase (Fig. 5) and peroxidase (Fig. 6) showed a significant increase in tomato seedlings under osmotic stress conditions, which were effective in alleviating the adverse impact of ROS and subsequently preventing lipid peroxidation. Foliar application of EBL and $\mathrm{N}-\mathrm{ZnO}$ resulted in increased activity of both CAT and POD, especially when no osmotic stress was imposed on tomato seedlings. This may also imply that CAT plays more important role than POD in scavenging excessive hydrogen peroxide in osmotic stress condition. This is in consistency with the same report in silicon-supplemented tomato seedlings exposed to water deficit stress (Shi et al., 2014). Yuan et al. (2010) reported that the use of epibrassinolide induced tolerance to drought in tomato via reducing malondialdehyde and hydrogen peroxide and increasing the activity of antioxidant enzymes. Researchers believe that brassinosteroids increase the resistance of plants to ROS-mediated oxidative damage through the modulation of expression of genes encoding antioxidative enzymes (Goda et al., 2002; Cao et al., 2005). Zinc is effective in the induction of gene expression responsible for the synthesis of proteins and antioxidant enzymes and in some cases, is also considred a cofactor for these enzymes (Grewal and Wiliams, 2000; Bagci et al., 2007; Alharby et al., 2016).

\section{Conclusion}

Finally, it could be concluded that seeds produced from tomato plants, which were treated with 24-epibrassinolide and nano-zinc oxide, showed higher tolerance to osmotic stress. So that seed germination indices, seedling growth performance and activity of antioxidative enzymes were significantly increased by preventing the accumulation of toxic ROS and MDA as the main peroxidative products. Although, both two applied concentrations of 24-epibrassinolide and nano-zinc oxide showed the promotive effects on osmotic stress tolerance in tomato seedlings, the combined treatment of $30 \mathrm{mg}^{-\mathrm{ha}^{-1}} 24-$ epibrassinolide and $1200 \mathrm{ppm}$ nano-zinc oxide $\left(\mathrm{EBL}_{2}+\mathrm{N}-\mathrm{ZnO}_{2}\right)$, had higher tolerance capability. Based on the current findings, foliar application of 24-epibrassinolide and nano-zinc oxide with the optimal concentrations at the flowering stage is highly recommended. On the other hand, it is recommended that researchers investigate the effects of optimal concentrations of 24-epibrassinolide and nano-zinc oxide on different developmental stages of tomato seeds and report their results in order to complete the results of current study. 
Acknowledgements. The authors wish to thank the Research and Financial Deputy staff in the University of Mohaghegh Ardabili and the Seed Production Company 'Falat'. As well, Dr. Rostami's (Faculty member of Malayer University) compassionate advice is appreciated.

\section{REFERENCES}

[1] Aebi, H. (1984): Catalase in vitro. - Methods in Enzymology 105: 121-126.

[2] Agrawal, S., Rathore, P. (2014): Nanotechnology pros and cons to agriculture: a review. - Int J Curr Microbiol App Sci 3: 43-55.

[3] Alharby, H. F., Metwali, E. M., Fuller, M. P., Aldhebiani, A. Y. (2016): Impact of application of zinc oxide nanoparticles on callus induction, plant regeneration, element content and antioxidant enzyme activity in tomato (Solanum lycopersicum Mill.) under salt stress. - Archives of Biological Sciences 68: 723-735.

[4] Alloway, B. J. (2004): Zinc in Soils and Crop Nutrition. - International Zinc Association, Brussels.

[5] Anjum, N. A. (2015): Book Review: Oxidative Damage to Plants-Antioxidant Networks and Signaling. - Frontiers in Plant Science 6: 452. DOI: 10.3389/fpls.2015.00452.

[6] Anonymous. (2016): FAO statistics division. - http://www.faostat.fao.org.

[7] Bagci, S., Ekiz, H., Yilmaz, A., Cakmak, I. (2007): Effects of zinc deficiency and drought on grain yield of field-grown wheat cultivars in central Anatolia. - Journal of Agronomy and Crop Science 193: 198-206.

[8] Bajguz, A. (2000): Effect of brassinosteroids on nucleic acids and protein content in cultured cells of Chlorella vulgaris. - Plant Physiology and Biochemistry 38: 209-215.

[9] Bates, L., Waldren, R., Teare, I. (1973): Rapid determination of free proline for waterstress studies. - Plant and Soil 39: 205-207.

[10] Baybordi, A. (2006): Zinc in Soils and Crop Nutrition. - Parivar Press, Tehran.

[11] Behnamnia, M., Kalantari, K. M., Ziaie, J. (2009): The effects of brassinosteroid on the induction of biochemical changes in Lycopersicon esculentum under drought stress. Turkish Journal of Botany 33: 417-428.

[12] Bhatt, R. M., Selvakumar, G., Upreti, K. K., Boregowda, P. C. (2015): Effect of biopriming with Enterobacter strains on seed germination and seedling growth of tomato (Solanum lycopersicum L.) under osmotic stress. - Proceedings of the National Academy of Sciences, India Section B: Biological Sciences 85: 63-69.

[13] Biesaga-Koscielniak, J., Dziurka, M., Ostrowska, A., Mirek, M., Koscielniak, J., Janeczko, A. (2014): Brassinosteroid improves content of antioxidants in seeds of selected leguminous plants. - Australian Journal of Crop Science 8: 378.

[14] Bindraban, P. S., Dimkpa, C., Nagarajan, L., Roy, A., Rabbinge, R. (2015): Revisiting fertilisers and fertilisation strategies for improved nutrient uptake by plants. - Biology and Fertility of Soils 51: 897-911.

[15] Boonchuay, P., Cakmak, I., Rerkasem, B., Prom-U-Thai, C. (2013): Effect of different foliar zinc application at different growth stages on seed zinc concentration and its impact on seedling vigor in rice. - Soil Science and Plant Nutrition 59: 180-188.

[16] Cakmak, I. (2000): Tansley Review No. 111 Possible roles of zinc in protecting plant cells from damage by reactive oxygen species. - The New Phytologist 146: 185-205.

[17] Calvo-Polanco, M., Sánchez-Romera, B., Aroca, R., Asins, M. J., Declerck, S., Dodd, I. C., Martínez-Andújar, C., Albacete, A., Ruiz-Lozano, J. M. (2016): Exploring the use of recombinant inbred lines in combination with beneficial microbial inoculants (AM fungus and PGPR) to improve drought stress tolerance in tomato. - Environmental and Experimental Botany 131: 47-57.

[18] Cao, S., Xu, Q., Cao, Y., Qian, K., An, K., Zhu, Y., Binzeng, H., Zhao, H., Kuai, B. (2005): Loss-of-function mutations in DET2 gene lead to an enhanced resistance to oxidative stress in Arabidopsis. - Physiologia Plantarum 123: 57-66. 
[19] Chandrasekaran, P., Sivakumar, R., Nandhitha, G., Vishnuveni, M., Boominathan, P., Senthilkumar, M. (2017): Impact of PPFM and PGRs on seed germination, stress tolerant index and catalase activity in tomato (Solanum lycopersicum L) under drought. - Int. J. Curr. Microbiol. App. Sci 6: 540-549.

[20] Copeland, L. O. Mcdonald, M. F. (2012): Principles of Seed Science and Technology. Springer Science and Business Media, New York.

[21] De Figueiredo E Albuquerque, M., De Carvalho, N. (2003): Effect of the type of environmental stress on the emergence of sunflower (Helianthus annus L.), soybean (Glycine max (L.) Merril) and maize (Zea mays L.) seeds with different levels of vigor. Seed Science and Technology 31: 465-479.

[22] Delauney, A., Hu, C., Kishor, P., Verma, D. (1993): Cloning of ornithine deltaaminotransferase cDNA from Vigna aconitifolia by trans-complementation in Escherichia coli and regulation of proline biosynthesis. - Journal of Biological Chemistry 268: 18673-18678.

[23] Delay, M. (2017): Microcantilever investigation of nanoconfinement effects on water transport. - Biophysical Journal 112: 157a.

[24] Divi, U. K. Krishna, P. (2010): Overexpression of the brassinosteroid biosynthetic gene AtDWF4 in Arabidopsis seeds overcomes abscisic acid-induced inhibition of germination and increases cold tolerance in transgenic seedlings. - Journal of Plant Growth Regulation 29: 385-393.

[25] Eevera, T., Vanangamudi, K. (2006): Tomato. - In: Vanangamudi, K., Natarajan., N., Srimathi., P., Natarajan., K., Saravanan., T., Bhaskaran., M., Bharathi., A., Natesan., P., Malarkodi, K. (eds.) Advances in Science and Technology. Quality Seed Production in Vegetables. Agrobios, India.

[26] Erik, T., David, N., Orcutt, M. (1996): The Physiology of Plants under Stress, Abiotic Factors. - Wiley, New York.

[27] Eisvand, H., Tavakkol-Afshari, R., Sharifzadeh, F., Maddah Arefi, H., Hesamzadeh Hejazi, S. (2010): Effects of hormonal priming and drought stress on activity and isozyme profiles of antioxidant enzymes in deteriorated seed of tall wheatgrass (Agropyron elongatum Host). - Seed Science and Technology 38: 280-297.

[28] Elias, S., Garay, A., Schweitzer, L., Hanning, S. (2006): Seed quality testing of native species. - Native Plants Journal 7: 15-19.

[29] Ellis, R., Roberts, E. (1981): The quantification of ageing and survival in orthodox seeds. - Seed Science and Technology 9: 373-409.

[30] Finch-Savage, B. (2013): Seeds: Physiology of Development, Germination and Dormancy. - Cambridge University Press, Cambridge.

[31] George, R. A. (2009): Vegetable Seed Production. - CABI, Wallingford, UK.

[32] Gill, S. S., Tuteja, N. (2010): Reactive oxygen species and antioxidant machinery in abiotic stress tolerance in crop plants. - Plant Physiology and Biochemistry 48: 909-930.

[33] Goda, H., Shimada, Y., Asami, T., Fujioka, S., Yoshida, S. (2002): Microarray analysis of brassinosteroid-regulated genes in Arabidopsis. - Plant Physiology 130: 1319-1334.

[34] Grewal, H. S., Williams, R. (2000): Zinc nutrition affects alfalfa responses to water stress and excessive moisture. - Journal of Plant Nutrition 23: 949-962.

[35] Haslett, B., Reid, R., Rengel, Z. (2001): Zinc mobility in wheat: uptake and distribution of zinc applied to leaves or roots. - Annals of Botany 87: 379-386.

[36] Hayat, S., Ahmad, A., Mobin, M., Fariduddin, Q., Azam, Z. (2001): Carbonic anhydrase, photosynthesis, and seed yield in mustard plants treated with phytohormones. Photosynthetica 39: 111-114.

[37] Heath, R. L., Packer, L. (1968): Photoperoxidation in isolated chloroplasts: I. Kinetics and stoichiometry of fatty acid peroxidation. - Archives of Biochemistry and Biophysics 125: 189-198. 
[38] Hossain, M. A., Hoque, M. A., Burritt, D. J., Fujita, M. (2014): Proline Protects Plants against Abiotic Oxidative Stress: Biochemical and Molecular Mechanisms. Oxidative Damage to Plants. - Elsevier, San Diego, USA, pp. 477-522.

[39] Hung S-H, Yu C-W, Lin, C. H. (2005): Hydrogen peroxide functions as a stress signal in plants. - Bot. Bull. Acad. Sin. 46: 1-10.

[40] ISTA (2008): International Rules for Seed Testing. Rules 2008. - International Seed Testing Association.

[41] Khripach, V. A., Zhabinskii, V. N., De Groot, A. E. (1998): Brassinosteroids: a New Class of Plant Hormones. - Academic Press, San Diego.

[42] Kishor, K., Polavarapu, B., Sreenivasulu, N. (2014): Is proline accumulation per se correlated with stress tolerance or is proline homeostasis a more critical issue? - Plant, Cell and Environment 37: 300-311.

[43] Laware, S., Raskar, S. (2014): Influence of zinc oxide nanoparticles on growth, flowering and seed productivity in onion. - Int J Curr Microbiol Appl Sci 3: 874-881.

[44] Macadam, J. W., Nelson, C. J., Sharp, R. E. (1992): Peroxidase activity in the leaf elongation zone of tall fescue I. Spatial distribution of ionically bound peroxidase activity in genotypes differing in length of the elongation zone. - Plant Physiology 99: 872-878.

[45] Marschner, H. (2011): Marschner's Mineral Nutrition of Higher Plants. - Academic Press, Amsterdam.

[46] Mignolet-Spruyt, L., Xu, E., Idänheimo, N., Hoeberichts, F. A., Mühlenbock, P., Brosché, M., Van Breusegem, F., Kangasjärvi, J. (2016): Spreading the news: subcellular and organellar reactive oxygen species production and signalling. - Journal of Experimental Botany 67: 3831-3844.

[47] Mittova, V., Volokita, M., Guy, M. (2015): Antioxidative Systems and Stress Tolerance: Insight from Wild and Cultivated Tomato Species. - In: Gupta, K. J., Igamberdiev, A. U. (eds.) Reactive Oxygen and Nitrogen Species Signaling and Communication in Plants (pp. 89-131). - Springer International Publishing, Switzerland.

[48] Movahhedy-Dehnavy, M., Modarres-Sanavy, S. A. M., Mokhtassi-Bidgoli, A. (2009): Foliar application of zinc and manganese improves seed yield and quality of safflower (Carthamus tinctorius L.) grown under water deficit stress. - Industrial Crops and Products 30: 82-92.

[49] Mura, S., Seddaiu, G., Bacchini, F., Roggero, P. P., Greppi, G. F. (2013): Advances of nanotechnology in agro-environmental studies. - Italian Journal of Agronomy 8: 18.

[50] Özdemir, F., Bor, M., Demiral, T., Türkan, İ. (2004): Effects of 24-epibrassinolide on seed germination, seedling growth, lipid peroxidation, proline content and antioxidative system of rice (Oryza sativa L.) under salinity stress. - Plant Growth Regulation 42: 203211.

[51] Peng, Y.-M., Shi, G.-L., Cui, H.-M. (2013): Evaluation of drought resistant of different processing tomato at seed germination stage under pEG-6000 stress. - Seed 7: 012.

[52] Petrov, V., Hille, J., Mueller-Roeber, B., Gechev, T. S. (2015): ROS-mediated abiotic stress-induced programmed cell death in plants. - Frontiers in Plant Science 6.

[53] Pfeifer, A. A., Murata, V. V., Barrozo, M. A. (2011): Analysis of seed quality and drying performance of a multistage countercurrent sliding-bed dryer. - Chemical Engineering and Technology 34: 234-240.

[54] Prasad, T., Sudhakar, P., Sreenivasulu, Y., Latha, P., Munaswamy, V., Reddy, K. R., Sreeprasad, T., Sajanlal, P., Pradeep, T. (2012): Effect of nanoscale zinc oxide particles on the germination, growth and yield of peanut. - Journal of Plant Nutrition 35: 905-927.

[55] Prusakova, L., Chizhova, S., Ageeva, L., Golantseva, E., Yakovlev, A. (2000): Effects of Epibrassinolide and Ekost on the drought resistance and productivity of spring wheat. Agrokhimiya 2000(5): 50-54.

[56] Puthur, J. T. (2016): Antioxidants and cellular antioxidation mechanism in plants. - South Indian Journal of Biological Sciences 2: 14-17. 
[57] Rajabi, M., Elhami, F., Fetri, M. (2013): Osmopriming effects on germination and seedling growth of Calendula officinalis L. - International Journal of Agriculture and Crop Sciences 6: 9.

[58] Rashid, M., Singh, D. (2000): A manual on Vegetable Seed Production in Bangladesh. AVRDC-USAID-Bangladesh Project. - Horticulture Research Centre, Bangladesh Agricultural Research Institute, Rajshahi.

[59] Rehman, S., Harris, P., Bourne, W. (1999): Effect of artificial ageing on the germination, ion leakage and salinity tolerance of Acacia tortilis and A. coriacea seeds. - Seed Science and Technology 27: 141-149.

[60] Rejeb, K. B., Abdelly, C., Savouré, A. (2014): How reactive oxygen species and proline face stress together. - Plant Physiology and Biochemistry 80: 278-284.

[61] Rengel, Z. (1995): Sulfhydryl groups in root-cell plasma membranes of wheat genotypes differing in Zn efficiency. - Physiologia Plantarum 95: 604-612.

[62] Rengel, Z., Wheal, M. S. (1997): Kinetic parameters of Zn uptake by wheat are affected by the herbicide chlorsulfuron. - Journal of Experimental Botany 48: 935-941.

[63] Sangkram, U., Noomhorm, A. (2002): The effect of drying and storage of soybean on the quality of bean, oil, and lecithin production. - Drying Technology 20: 2041-2054.

[64] Sedghi, M., Hadi, M., Toluie, S. G. (2013): Effect of nano zinc oxide on the germination parameters of soybean seeds under drought stress. - Annals of West University of Timişoara, Ser. Biology 16: 73-78.

[65] Shi, Y., Zhang, Y., Yao, H., Wu, J., Sun, H., Gong, H. (2014): Silicon improves seed germination and alleviates oxidative stress of bud seedlings in tomato under water deficit stress. - Plant Physiology and Biochemistry 78: 27-36.

[66] Srivastava, A., Handa, A. K. (2005): Hormonal regulation of tomato fruit development: a molecular perspective. - Journal of Plant Growth Regulation 24: 67-82.

[67] Steber, C. M., Mccourt, P. (2001): A role for brassinosteroids in germination in Arabidopsis. - Plant Physiology 125: 763-769.

[68] Sun, W., Wu, Y., Wen, X., Xiong, S., He, H., Wang, Y., Lu, G. (2016): Different mechanisms of photosynthetic response to drought stress in tomato and violet orychophragmus. - Photosynthetica 54: 226-233.

[69] Szabados, L., Savouré, A. (2010): Proline: a multifunctional amino acid. - Trends in Plant Science 15: 89-97.

[70] Taiz, L., Zeiger, E., Møller, I. M., Murphy, A. (2015): - Plant Physiology and Development. - Sinauer Associates, Sunderland MA.

[71] Talaat, N. B., Shawky, B. T. (2013): 24-Epibrassinolide alleviates salt-induced inhibition of productivity by increasing nutrients and compatible solutes accumulation and enhancing antioxidant system in wheat (Triticum aestivum L.). - Acta Physiologiae Plantarum 35: 729-740.

[72] Tavallali, V., Rahemi, M., Eshghi, S., Kholdebarin, B., Ramezanian, A. (2010): Zinc alleviates salt stress and increases antioxidant enzyme activity in the leaves of pistachio (Pistacia vera L. 'Badami') seedlings. - Turkish Journal of Agriculture and Forestry 34: 349-359.

[73] Todorova, D., Neveen, B., Katerova, Z., Alexieva, V., Shawky, B. T. (2016): Polyamines and Brassinosteroids in Drought Stress Responses and Tolerance in Plants. - In: Ahmad, P. (ed.) Water Stress and Crop Plants: A Sustainable Approach. Vol. 2. pp. 608-627. Wiley-Blackwell, Chicester.

[74] Uzilday, B., Turkan, I., Ozgur, R., Sekmen, A. H. (2014): Strategies of ROS regulation and antioxidant defense during transition from $\mathrm{C} 3$ to $\mathrm{C} 4$ photosynthesis in the genus Flaveria under PEG-induced osmotic stress. - Journal of Plant Physiology 171: 65-75.

[75] Vardhini, B. V., Anuradha, S., Sujatha, E., Rao, S. S. R. (2010): Role of brassinosteroids in alleviating various abiotic and biotic stresses-a review. - Plant Nutrition and Abiotic Stress Tolerance I. Plant Stress 4: 55-61. 


$$
-4417 \text { - }
$$

[76] Welch, R. (2001): Impact of Mineral Nutrients in Plants on Human Nutrition on a Worldwide Scale. - In: Horst W. J. et al. (eds.) Plant Nutrition. Developments in Plant and Soil Sciences. Vol. 92, pp. 284-285. Springer, Dordrecht.

[77] Yuan, G.-F., Jia, C.-G., Li, Z., Sun, B., Zhang, L.-P., Liu, N., Wang, Q.-M. (2010): Effect of brassinosteroids on drought resistance and abscisic acid concentration in tomato under water stress. - Scientia Horticulturae 126: 103-108.

[78] Zhang, S., Cai, Z., Wang, X. (2009): The primary signaling outputs of brassinosteroids are regulated by abscisic acid signaling. - Proceedings of the National Academy of Sciences 106: 4543-4548. 